\title{
Perspektívy Teatrológie 2019
}

\author{
Ivona Solčániová
}

Perspektivy teatrologie. Akademická konference pořádaná Teatrologickou společností ve spolupráci s Katedrou divadelních studií FF MU Brno, Divadelním oddělením Moravského zemského muzea, Institutem umění Divadelním ústavem a časopisem Divadelni revue, 15.-17. května 2019, Dietrichsteinský palác v Brně.

Po Prahe a Olomouci sa v poradí tretí ročník Perspektív teatrológie odohrával v Brne, počas 15. až 17. mája. Centrom diania sa stala hlavná sála Dietrichsteinského paláca na Zelném trhu. Umiestnenie Perspektív práve na toto miesto sa osvedčilo ako vhodne zvolená stratégia. Dietrichsteinský palác, ktorý je súčastou budovy Moravského zemského múzea obklopujú dve divadelné scény: alternatívna scéna divadla Husa na provázku a historická budova Reduty. Priestor paláca sa tak na tri dni stal miestom horlivých diskusií nad aktuálnym otázkami a bádaním z oblasti (nielen českej) teatrológie.

Prednáškové cykly sa tematicky rozdelovali do väčších celkov, ktoré sa skladali z kratších referátov 2-3 prednášajúcich s priestorom pre diskusiu. Tematicky dominovali príspevky z českého divadelného prostredia, za ktorými nezaostávala ani oblast' podchycujúca slovenské divadlo. Námety príspevkov boli rôznorodé: od staršieho cez moderné divadlo, avantgardu, po aktuálne divadelné dianie. Širší priestor dostalo tanečné umenie, muzikál, svetelný dizajn a téma ekológie v divadle.

Komornejší a rozvol'nenejší program sa presúval do ned’alekej kaviarne Trojka, ktorá okrem priestoru pre živú vravu, slúžila k prezentácií kníh z oblastí divadla.

Úvodného slova sa ujali David Drozd z brnenskej Katedry divadelných štúdií a Jaroslav Blecha z Divadelného oddelenia Moravského zemského múzea. Po krátkom predstavení tohtoročných perspektív a privítaní účastníkov sa cyklus prednášok otvoril témami podchycujúcimi staršie divadlo.

Sylvia Pracná nás zoznámila s premenami nemeckojazyčného Mestského divadla v Krnove, kde sa autorka zameriavala najmä na divadelný priestor a podmienky prevádzky divadla. Nasledujúci príspevok Martina Timka predstavil pripravovanú monografiu dramatika Jána Palárika $P a$ lárik žije!. Súborné Palárikovo dielo (v zložení troch veselohier a jednej truchlohry) písané pôvodne v staršom archaickom jazyku, by sa tak malo približovat' súčasnej podobe slovenského jazyka. Zároveň autor analyzoval rôzne prístupy k výskumu a vylíčil zložitost̉ práce s dramatickým textom. Záverečný príspevok celku uzatvárali okolnosti spojené s poslednou verziou opery Ludwiga van Beethovena Fidelio. Martin Hanoušek v príspevku ozrejmil zaužívanú prax skladatel'a a libretistu opery s intendantmi divadiel. V tomto prípade sa Beethovenova korešpondencia javí ako jeden z podstatných prameňov pri divadelno-historickom výskume.

Nasledujúci okruh reflektujúci scénografiu poukázal na medzery nejednoznačnej terminológie oboru, hraničiaceho medzi výtvarným umením a divadlom. Věra 
Velemanová vychádzajúca zo štúdií Věry Ptáčkovej, prezentovala nové možnosti teoretického a historického poňatia scénografického tvaru. Svoje štúdie obohatila o obrazové ukážky akčnej scénografie na Morave. Náhlad na scénografiu z pozície kunsthistorika spracovala Zuzana Koblišková vo svojom príspevku o výtvarných perspektívach Ladislava Vychodila. Autorka sa zamerala najmä na Vychodilovú precíznu prácu so svetlom pri scénografických riešeniach Shakespeara. Otvorila polemiku nad témou, "AKO?" a “ČI?” je možné vystavovat’ scénografiu.

Na scénografický celok logicky nadväzoval okruh zohladňujúci divadelný priestor a dizajn. Výskum grafického dizajnu demonštroval Martin Maryška na ukážkach divadelných plagátov od Borisa Myslivečka pre inscenácie Husy na provázku. Vychádzal zo záveru, že propagačná grafika môže mat schopnost' rozširovat priestor javiska a tak byt súčastou scénografického riešenia. Od grafických návrhov divadelných plagátov sme sa presunuli k svetelnému dizajnu v referáte praktika Vladimíra Buriana. Poukázal na nedostatočnú a často obchádzanú reflexiu svetla $\mathrm{v}$ divadle. Za hlavné kritérium pri hodnotení daného elementu prirodzene označil zrak a viacvýznamovost' reakcií l'udského oka na osvetlenie. "Jak moc se liši recepce v rámci klasického divadla při umělém osvětleni a (např́klad) site specific při denním osvětleni? A jak se vůbec liši zrakové vnimáni diváka $v$ divadle oproti vnimani v běžném životěe?" (BURIAN 2019)

Ďalší z rady osobitých príspevkov od Miroslava Jurániho otvoril aktuálne témy ekologického myslenia v divadle. Zároveň skúmal dramatické predlohy inscenácií a rôzne podoby performancie $\mathrm{z}$ hladiska myslenia o dopade l'udskej činnosti na životné prostredie. „Platí premisa, ktorú vyslovila teatrologicka Una Chaudhuri, že divadlo je od podstaty anti-ekologické? Že aj ked'sa dráma zaoberá ekologickým problémom, nevyhne sa tomu, že existuje iba v divadelnej estetike a ideológii v centre ktorej vždy stoji člověk. " (JURÁNI 2019)

Večer sa zakončil neformálnym spoločenským stretnutím v Trojke. Priestor kaviarne našiel využitie ako provizórne kníhkupectvo odbornej literatúry. Zároveň prebehla prezentácia aktuálnej publikačnej činnosti prítomných vydavatelstiev. Rozprávalo sa napríklad o novej publikácií autorky Ivy Mikulovej, monografii Divadelni režisér Karel Novák (1916-1968)¹, taktiež snád' o „najmladšom“ výtlačku rozhlasových rozhovorov s Bořivojom Srbom Divadlo, mi̊j osud.

Nasledujúci deň patril tematicky divadelnej avantgarde a neopomenul ani doposial' nediskutované oblasti - tanec a muzikál. Jitka Goriaux Pelechová dokončuje habilitačnú prácu venovanú tvorbe francúzskeho režiséra Antoina Viteze. Autorka sa taktiež zameriava na pedagogickú činnost' režiséra. Výskum podopiera o zachovaný záznam z dvanástich Vitezových hereckých lekcií, v ktorých študenti konzervatória princípom montáží a improvizácií spracovávajú politickú tému.

Karol Mišovic venuje pozornost' histórií slovenského ženského herectva. Tentokrát predstavil jednu z popredných osobností začínajúceho profesionálneho divadla na Slovensku, herečku Ol'gu Borodáčovú Országhovú. Širokým obrazovým materiálom sprítomnil herecký štýl

1 Práca bola ocenená v kategórií „dizertačných prác“ Cenou Václava Königsmarka v roku 2018. 
osobnosti vychádzajúci z psychologicko-realistického divadla. Neopomenul ani herečkine neskoršie polohy na ukážke z Brechtovej hry Život Galileiho v réžií Tibora Rakovského.

Divadelná historička a kritička Tatjana Lazorčáková následne predstavila závery výskumu divadelnej kritiky profesionálneho činoherného divadla v Ostrave a Olomouci počas "zlatých“ 60. rokov. Autorka sprostredkovala svoje nelahké skúsenosti s dešifrovávaním autorských skratiek divadelných kritikov. Výskum prehlásila autorka za zdarný. Výstup Tatjany Lazorčákovej bude mat podobu lexikónu osobností divadelnej kritiky v Ostrave a Olomouci počas rokov 1956 až 1970. Štúdia plánuje obsahovat celkovo 18 osobných hesiel vrátane príkladových recenzií.

Konferenčné referáty neobišli ani pražskú avantgardnú scénu z konca 30. rokov. Voskovec s Werichom objavili aktuálnost diela Pietera Brueghela staršieho skrz sprítomnenie autorových obrazov na scénu Oslobodeného divadla. Eva Šlaisová v príspevku rekonštruovala formálne rysy inscenácie Tězké Barbory z perspektívy brueghelovskej poetiky. Odkrývala rôzne významové vrstvy obrazov - témy ludovosti, karnevalovosti a okupácie. Súčasne podotkla, že v českom prostredí ide o najoriginálnejšiu transpozíciu Brueghelových obrazov do divadelnej podoby.

Martin Bernátek otvoril tému estetiky divadelného priestoru na príklade projektu Divadla práce E. F. Buriana a M. Kouřila. Súčastou obrazového materiálu boli pôdorysy a architektonické návrhy divadla vrátane možných variácií divadelného priestoru. $\mathrm{V}$ príspevku sa odkláña od estetizujúceho výkladu medzivojnovej avantgardy a zameriava sa na ideologické predpoklady a politické efekty spojené so študovaným predmetom.

Následne sa David Drozd pozastavil pri komplikovanej osobnosti režiséra Jindřicha Honzla, ktorú zasadil do kontextu českého divadla 50. rokov. Na základe vybraných textov (predovšetkým nekrológov) sa pokúšal demonštrovat' obraz Honzla v dobovom diskurze. Zároveň predostieral stratégie, aké volia autori písuci o osobnosti režiséra: Honzl ako pokrokový komunistický tvorca, Honzl ako obet, ako surrealista, sarkastický pedagóg?

Doteraz nediskutovanú oblast' tanečného umenia otvorila Kateřina Audy, ktorá predstavila súbor Národného divadla v Prahe v kontexte dobových politických pomerov z 20. storočia. Históriu baletu sleduje od nástupu R. Remislavského v roku 1923. Postupne predstavuje pomery súboru počas búrlivého striedania umeleckých vedúcich, až do obdobia vedenia Jiř́ho Němečka v roku 1989. Baletom tematicky pokračovala teatrologička Julie Kočí. Politické aspekty v období normalizácie sledovala na príklade komponovaného večera Čas člověka, uvedeného v máji 1980 baletom Národného divadla v Prahe ako slávnostná premiéra $\mathrm{k}$ výročiu oslobodenia Československa.

Po predstavení príspevkov z tanečného umenia nasledovala časṫ orientovaná na nové, resp. existujúce projekty $\mathrm{v}$ oblasti divadla. Prvá čast určená projektu Európskeho sociálneho fondu: Vzdelávanie divadlom $^{2}$ (vedený profesorkou Dagmar Inštitorisovou počas rokov 2010 až 2014), predstavil platformu na podporu inovácií

2 Odkaz na projekt: http://www.vzdelavaniedivadlom.ukf.sk/oprojekte.htm. 
metód výučby pomocou divadelných prístupov k výuke. Druhá čast’ profesorkinho výkladu neobišla projekt Fondu na podporu umenia: Milan Rastislav Štefánik v dramatickej tvorbe na Slovensku a v Čechách. Monografia charakterizuje M. R. Štefánika ako dramatickú a dokumentárnu postavu z pohladu aktuálnych českých a slovenských divadelných, rozhlasových či televíznych diel.

Letnú školu Jaroměřr-Josefov môžeme očakávat aj v priebehu posledného augustového týždňa. Dvaja z organizátorov, Lukáš Kubina a Martin Bernátek, predostreli aktivity školy a náplň tohtoročných workshopov. Hlavná téma „What does university mean today?"3, bude zameraná na pozíciu univerzity $\mathrm{v}$ širšom sociálnom merítku. ${ }^{4}$

Medzi projekty sa právom zaradil aj príspevok Terezy Zálešákovej, ktorá momentálne pracuje na svojej dizertačnej práci mapujúcej český muzikál po roku 1989. Autorka sa dotkla súčasnej pozície žánru v akademickom diskurze a upozornila na možné dôsledky pretrvávajúceho nezáujmu českej teatrológie prijat’ muzikál ako predmet odborného skúmania. Uviedla príklad z The Cambridge Companion to the Musical, kde autorky označujú muzikálovú adaptáciu Dvořákovy Rusalky a Ledeckého Hamleta za najpozoruhodnejšie muzikály novej éry.

Svoje okrúhle narodeniny oslávila Cena Václava Königsmarka, ktorej 10. ročník sa neniesol výlučne v duchu odovzdávania cien za úspešné záverečné práce študentov

3 Summer School Jaroměř-Josefov. https://divadlo.phil.muni.cz/josefov, 2019, [ cit. 14. 6. 2019 ]. Dostupné na webovskej stránke (world wide web): http://divadlo.phil.muni.cz/josefov.

4 Ibid. divadelnej vedy. Večer sa zakončil spoločenským „brainstormingom“ nad uplynulými dňami perspektív a inými (nielen) teatrologickými témami.

Rovno prejdeme k vyhodnoteniu tohtoročných Cen Václava Königsmarka, ktorej odborná komisia v zložení David Drozd, Andrea Jochmanová, Lenka Jungmanová, Alena Sarkissian, Helena Spurná, Barbora Topolová a Libor Vodička, vybrala spomedzi prihlásených prác nasledovné: 5

Bakalárske práce (uvádzam v poradí od prvého po tretie umiestnenie): Amália $\mathrm{Bu}$ landrová: Proměny Pražského Quadriennale: Promény a posuny zpuisobri vystavováni divadelni scénografie se zaměrením na ročniky 2007, 2011 a 2015, Ivona Solčániová: Budova Horáckého divadla v jihlave a Petra Zachatá: Proměny dramatické formy: Propojeni dramatické a postdramatické poetiky ve hrách Rolanda Schimmelpfenniga.

Magisterské práce (uvádzam v poradí od prvého po tretie umiestnenie): Lukáš Černý: Tragický jazyk mlčení. Euripidova Alkestis na pomezi žánru tragédie, Tereza Richterová: Obraz a pojetí lidského těla v díle Marie Chouinard a Eliška Šolcová: Listy heroin aneb šest antických hrdinek pro současné jeviště.

Spomedzi dizertačných prác porota ohodnotila prvou cenou prácu Terezy Konývkovej: Tělo v pohybu: performativita sokolského hnuti v obdobi formováni moderniho českého národa. Čestné ocenenie patrilo Miroslavovi Lukášovi za prácu Divadlo v Mikulově za éry rodu Dietrichsteinů (od konce 16. století do druhé světové války) a Janovi Sukovi za prácu The Poetics of Immanence: Performance Theater of Forced Entertainment. Stručný obsah vítazných prác a fotogalériu

5 Zrov.: Cena Václava Königsmarka. http://www. teatrologie.cz/, 2019, [ cit. 14. 6. 2019 ]. Dostupné online: http:/ / www.teatrologie.cz/konigsmark. 
$\mathrm{z}$ večera nájdete $\mathrm{v}$ priloženom odkaze pod článkom. ${ }^{6}$

Záverečný deň perspektív otvorila Andrea Jochmanová s príspevkom „Rekonstrukce historie divdla jako tvůrčí proces“, v ktorom polemizuje nad dôležitými faktormi dopomáhajúcimi $\mathrm{k}$ prezentácií vedeckých záverov. U osoby divadelného historika vyzdvihuje primárne vášeň a schopnost „vyrozprávat"“ príbeh. Klára Hanáková upozornila na zaujímavú etapu režiséra Zdenka Pospíšila, ktorú strávil vo švajčiarskom exile v rokoch 1980 až 1989. Zmienené boli pohostinské réžie v Grécku a Francúzsku, ktoré doplnila o ukážku z jedného z najúspešnejších režijných počinov Nejlokomotivovatějši lokomotiva, vytvorený vo švajčiarskom Lausanne.

$\mathrm{Na}$ čo sa môžeme v najbližšom období tešit je finišujúci zväzok, výber dvadsiatich dramatických textov domácich a zahraničných autorov, ktorí sú s českým prostredím prepojení rôznymi väzbami. Antológiu Expresionistické drama z českých zemi predstavili autori projektu Zuzana Augustová a Aleš Merenus. Spomedzi vybraných drám uvedú fragment Kafkovej hry Strážce hrobky, Brodovu jednoaktovku Vykupitelka a hru Návštěva z Elízia od Franza Werfela.

Predmetom nasledujúcich úvah bola nezávislá scéna divadla Pôtoň. Ide o jediné profesionálne divadlo na Slovensku pôsobiace mimo vel'kých miest. Poetiku divadla a interpretačné princípy režisérky Ivety Ditte Jurčovej a dramaturga Michala Ditteho predstavil kulturológ Michal Ballay na ukážkach zo scénickej eseje Pastierska symfónia. Lukáš Brychta a Sarah Komasová

6 Odkaz na výsledky 10. ročníka "CVK": http:// www.teatrologie.cz/konigsmark. diskutovali zaujímavý prístup k výskumu mapujúcom chovanie diváka v interaktívnom priestore „one-on-one“ divadla a to na základe kvantitatívnych a kvalitatívnych výskumných metód.

V záverečnom príspevku k témam nezávislého divadla predstavila Veronika Kyrianová nový projekt Divadelného oddelenia Národného múzea, ktorý dokumentuje dielo a osobnost’ performerky Kači Olivovej. Opätovne sa otorila diskusia nad otázkou „ČI? a AKO?“ je možné dokumentovat' performanciu a happening.

Zástupcovia Divadelného oddelenia Národného múzea, Oddelenia dejín divadla Moravského zemského múzea a Ostravského divadelného archívu v krátkosti prezentovali aktuálnu výskumnú činnost', budúce plány a neobišli ani zaujímavé artefakty nachádzajúce sa vo fondoch inštitúcií. Išlo napríklad o vlasy Franza Liszta v zbierke Národného múzea, alebo nedofajčenú cigaru Aloisa Pivoňky v archíve Moravského zemského múzea. Za inštitúciami nasledovala prezentácia odborných časopisov: Theatralia a Divadelni revue, ktoré uzatvorili piatkový prednáškový celok.

Záverečné diskusie sa v krátkosti venovali aj rozširujúcemu sa fenoménu interdisciplinarity $\mathrm{v}$ teatrologickom bádaní. Ivona Solčániová demonštrovala aktuálny stav scénickej technológie na príklade vel'kých divadelných „barákov“ a Kateřina Šalounová prispela do diskusií svojimi profesionálnymi skúsenostami z oblastí tanečnej pedagogiky, ktoré prepája s teatrologickým zázemím.

Konferenciu sprevádzal program aj mimo prednáškových cyklov. V brnenskom Dome umenia prebiehala tematická výstava $L a$ terna magika: Dekonstrukce a aktualizace. Za 
zvýhodnené „konferenčné“ vstupné mohli účastníci navštívit večerné divadelné predstavenie Strýček Váňa v HaDivadle alebo Mariina volba v Huse na provázku.

Program tretieho ročníka Perspektív teatrológie bol zaujímavý v mnohých ohladoch. Ponúkol prehlad aktuálnych výskumov, pripravovaných projektov a publikácií, ktoré nás čakajú. Zároveň sme narazili na rôzne otázky a oblasti, ktoré divadelná vedy dostatočne nepodchycuje. Z konferencie sme tak odchádzali bohatší o množstvo zaujímavých postrehov a informácií.

\section{Bibliografie}

BURIAN, Vladimír. 2019. Světelný design jako poslední kauzální rámec divadla. In Program konference Perspektivy teatrologie 3. Brno: MUNI, 2019.

Cena Václava Königsmarka. Dostupné online http:/ / www.teatrologie.cz/

JURÁNI, Miloslav. 2019. Kulisy a postavy, príroda a človek. In Program konference Perspektivy teatrologie 3. Brno: MUNI, 2019.

Summer School Jaroměř-Josefov. Dostupné online https://divadlo.phil.muni.cz/josefov 